\title{
PERLINDUNGAN HUKUM BAGI BANK TERKAIT PERJANJIAN KREDIT KEPEMILIKAN RUMAH DENGAN PENGIKATAN SURAT KUASA MEMBEBANKAN HAK TANGGUNGAN DISERTAI PERJANJIAN BUY BACK GUARANTEE DI KOTA DENPASAR
}

\author{
I Nyoman Gede Paramartha*, Dr.Ni Ketut Supasti Darmawan, \\ SH.,MHum.,LLM*, I Nyoman Sumardika SH., M.Kn,* \\ Magister Kenotariatan Universitas Udayana \\ E-mail:paramartha_33@yahoo.com \\ ABSTRACT
}

\author{
LEGAL PROTECTION FOR BANKS ASSOCIATED AGREEMENT OF HOME \\ OWNERSHIP CREDIT WITH POWER OF ATTORNEY OF IMPOSING LIABILITY \\ RIGHTS ACCOMPANIEDBUYBACK GUARANTEE AGREEMENT IN DENPASAR
}

Home ownership credit faciliities are very much needed by the people who have low and medium buying power. In theory, as set forth in Article 1, paragraph (2) of the Regulation of the State Minister of Agrarian Services/Head of National Body for Land Affairs (BPN) No. 4 of 1996, with the binding of SKMHT is only granted to secure certain credits, i.e. to finance simple ownership, modest homes, condominiums with land area of $200 \mathrm{~m} 2$ and the building has not more than $70 \mathrm{~m} 2$. In practice many home ownership credit facilities are granted to buy a house with a land area of more than stated by the provision above. Problems also occurs with the provisions of Article 15 paragraph (1) of UUHT which require SKMHT regarding land rights which are already registred, SKMHT must be followed by the making of APHT as late as 1(one) month. Rights to land that has not been registered, should be followed by creating APHT as late as 3(three) months after the SKMHT is granted in accordance with Article 15 of UUHT paragraph (2). However, in granting Home ownership credit, the provision applied is Article 1, paragraph (2) of the Regulation of the State Minister of Agrarian Services/Head of Nation Body for Land Affairs (BPN) No. 4 of 1996 confirming that SKMHT is not mandatory until the end of the principal agreement. The principle issue in this study is the factors that cause the developer defaults on the SKMHT agreement completed with buy back guarantee and the efforts made by a bank if a developer defaults on yhe agreement of buy back guarantee.

Type of research used in this thesis was empirical legal research, which departed from the gap between Government Regulation State Minister of Agrarian Services/Head of Nation Body for Land Affairs (BPN) No. 4 of 1996, and the prevailing reality. The Approach used was a qualitative approach. Primary data collection technique was conducted using the method of taking sample interview with the Non-Random Sampling; secondary data collection was done through the technique of documentary studies and tertiary legal materials in the form of dictionaries and encyclopedias.

The results showed that the factors that caused the developer defaults on the agreement of SKMHT equipped with buyback guarantee are internal and external factors. The internal factor is the missue of credit facilities and bad character of developers. External factors that make economic recession are that the bank interest rate jump dramatically, as a result many debitors are unable to pay loans. Efforts made by the bank if a developer defaults on the agreement of buy back guarantee can be an effort in litigation and non-litigation paths. The best solution for creditors is through non-litigation paths.

Keywords: Power of Attorney Imposing Liability Rights (SKMHT), Home Ownership Credit (KPR), Providing Mortgage Deed (APHT)

\section{PENDAHULUAN}

\subsection{Latar Belakang}

Fasilitas KPR sangat dibutuhkan oleh masyarakat yang berdaya beli rendah dan menengah. KPR yang dimaksud dalam penelitian ini adalah program pemerintah yang dikenal dengan istilah Fasilitas Likuiditas Pembiayaan Perumahan, yang diatur di dalam Peraturan Menteri Negara 
Perumahan Rakyat Nomor 14 Tahun 2010 tentang Pengadaan Perumahan Melalui Kredit/Pembiayaan Pemilikan Rumah Sejahtera Dengan Dukungan Bantuan Fasilitas Likuiditas Pembiayaan Perumahan (selanjutnya disebut Peraturan Menpera 14/2010)

Secara teori sebagaimana diatur oleh Pasal 1 ayat (2) Peraturan Menteri Negara Agraria/Kepala BPN No. 4 tahun 1996, KPR dengan pengikatan SKMHT hanya diberikan untuk menjamin kredit-kredit sebagai berikut :

a. Kredit untuk membiayai pemilikan rumah sederhana, rumah sederhana, rumah susun dengan luas tanah $200 \mathrm{~m} 2$ dan luas bangunan tidak lebih dari $70 \mathrm{~m} 2$.

b. Kredit untuk kepemilikan kapling siap bangun (KSB) dengan luas tanah $54 \mathrm{~m} 2$ sampai dengan $72 \mathrm{~m} 2$ dan kredit untuk membiayai pembangunannya.

c. Kredit yang diberikan untuk pemugaran atau perbaikan rumah seperti yang dimaksud huruf a dan b.

Pada prakteknya banyak fasilitas KPR diberikan perbankan untuk membeli rumah dengan luas tanah lebih dari $200 \mathrm{~m} 2$ dengan luas bangunan lebih dari $70 \mathrm{~m} 2$. Selain itu terjadi permasalahan dalam kaitan dengan ketentuan dalam UUHT yang mengharuskan SKMHT diikuti pembuatan APHT. Pasal 15 ayat (1) UUHT mengharuskan SKMHT mengenai hak atas tanah yang sudah terdaftar diikuti dengan pembuatan APHT selambat-lambatnya 1 (satu) bulan. Sedangkan untuk hak atas tanah yang belum terdaftar, SKMHT harus diikuti pembuatan APHT selambatlambatnya 3 (tiga) bulan sesudah
SKMHT tersebut diberikan sesuai ketentuan Pasal 15 UUHT ayat (2). Dengan pemberian Hak Tanggungan melalui pendaftaran APHT maka akan terbit sertifikat Hak Tanggungan yang memiliki kekuatan eksekutorial sebagimana ketentuan Pasal 14 ayat (3) UUHT.

Tetapi dalam hal pemberian KPR, ketentuan yang diberlakukan adalah Pasal 1 ayat (2) Peraturan Menteri Negara Agraria/Kepala BPN No. 4 tahun 1996 yang menetapkan SKMHT tidak wajib diikuti oleh pembuatan APHT sampai dengan berakhirnya perjanjian pokok. Permasalahan muncul apabila developer wanprestasi terhadap perjanjian buy back gurantee, maka pihak bank akan kesulitan mendapatkan kembali hakhaknya, sekalipun pihak bank telah meminta jaminan lain berupa tanah dan bangunan kepada developer.

\subsection{Rumusan Masalah}

Dengan uraian latar belakang di atas maka rumusan masalah yang dikaji dalam penelitian ini adalah :

1. Faktor-faktor yang menyebabkan developer wanprestasi dalam pengikatan SKMHT yang dilengkapi perjanjian buyback guarantee?

2. Apakah upaya yang ditempuh oleh bank apabila developer wanprestasi terhadap perjanjian buy back guarantee?

\subsection{Tujuan Penelitian}

Tujuan penelitian ini dilakukan untuk mencapai tujuan yang bersifat umum dan tujuan yang bersifat khusus. 


\subsection{Manfaat Penelitian}

Dalam setiap penelitian harus dapat memberikan Manfaat Teoritis yaitu dapat mengembangkan ilmu hukum bidang kenotariatan. Manfaaat praktis memberi kontribusi bagi Kreditor, Debitor dan Developer dalam pelaksaan KPR

\subsection{Landasan Teoritis}

\subsubsection{Teori}

\section{a. Teori Perjanjian}

Teori Perjanjian adalah Teori Perjanjian menurut Mariam Darus Badrulzaman. Pada intinya teori itu berpendapat bahwa perjanjian mengandung asas kekuatan mengikat.

\section{b. Teori Stakeholder}

Teori Stakeholder menurut Eddie Sius Riyadi berpendapat bahwa kepentingan didasarkan pada pemahaman bahwa melampaui para pemegang saham, terdapat beberapa agen dengan sebuah kepentingan dalam tindakan dan keputusan perusahaan. ${ }^{1}$

\section{c. Teori Shareholder}

Teori shareholder yang digunakan dalam penelitian ini adalah menurut Gail Henderson yang mengatakan "In essence, the shareholder primacy principle holds that the sole duty of corporate directors is to maximize shareholder value". ("Teori Shareholder pada prinsipnya berpendapat bahwa satu-satunya tugas dari pengelola perusahaan adalah memaksimalkan nilai pemegang saham). ${ }^{2}$ Yang dimaksud

${ }^{1}$ Eddie Sius Riyadi, 2008, "Landasan Teoritis Bagi Tanggung Jawab Sosial Perusahaan : Dari Pemegang Saham (share holder) ke Pemangku Kepentingan (stake holder), Jurnal Ginitas, Volume V Nomor II, hal. 69

2 Gail Henderson, 2009, "The Possible Impact of Enlightened Share Holder Value on Corporation dengan "nilai pemegang saham" adalah nilai saham yang dimiliki para pemegang saham.

\subsubsection{Konsep}

1. Bank adalah badan usaha yang menghimpun dana dari masyarakat dalam bentuk simpanan dan menyalurkannya kepada masyarakat dalam bentuk kredit dan atau bentuk-bentuk lainnya dalam rangka meningkatkan taraf hidup orang banyak.

2. Bank Umum adalah Bank yang melaksanakan kegiatan usahanya secara konvensional dan atau berdasarkan prinsip syariah yang dalam kegiatannya memberikan jasa lalu lintas pembayaran.

3. Kredit Pemilikan Perumahan

(KPR) program pemerintah dalam pengadaan perumahan melalui kredit/pembiayaan pemilikan rumah sejahtera dengan dukungan bantuan fasilitas likuiditas pembiayaan perumahan.

4. Surat Kuasa Memberi Hak Tanggungan (SKMHT) dalam Penjelasan Pasal 15 ayat (1) UUHT, yaitu surat kuasa memberikan hak tanggungan yang merupakan perbuatan hukum membebankan Hak Tanggungan, tetapi tidak memuat hak untuk menggantikan penerima kuasa melalui pengalihan.

5. Hak Tanggungan (HT) dalam Pasal 1 ayat (1) UUHT menjelaskan definisi Hak Tanggungan, yaitu:

Hak Tanggungan adalah hak jaminan yang dibebankan pada hak atas tanah sebagaimana dimaksud dalam Undang-Undang No. 5 Tahun 1960 tentang Peraturan Dasar Pokok-Pokok Agraria berikut atau

Environmental Performance", A thesis submitted in conformity with the requirements for the degree of Master of Laws Graduate department of the Faculty of Law University of Toronto, page. 18 
tidak berikut benda-benda lain yang merupakan satu-kesatuan dengan tanah itu untuk pelunasan hutang tertentu, yang memberikan kedudukan yang diutamakan kepada kreditur terntu terhadap krediturkreditur lainnya.

6. Akta Pembebanan Hak Tanggungan (APHT) Menurut Pasal 1 angka (5) UUHT APHT adalah akta PPAT (Pejabat Pembuat Akta Tanah) yang berisi pemberian Hak Tanggungan kepada kreditor tertentu sebagai jaminan untuk pelunasan piutangnya.

7. Pengembang (developer) yaitu Badan usaha yang berbentuk badan hukum, yang berusaha dalam bidang pembangunan perumahan.

8. Buy Back Guarantee adalah penyelesaian total outstanding kredit debitur oleh developer.

9. Lokasi Penelitian, luas Wilayah Kota Denpasar 127,98 Ha yang merupakan 2,27 persen dari luas seluruh Pulau Bali. Jumlah penduduk Kota Denpasar berdasarkan Sensus Penduduk 2010 adalah 788.589 jiwa. Kota Denpasar merupakan pusat perdagangan Provinsi Bali.

\subsubsection{Pandangan Para Sarjana}

Pendapat Adrian Sutedi menjelaskan bahwa KPR adalah kredit yang diberikan bank kepada debitor untuk digunakan membeli atau membayar sebuah rumah tinggal dengan tanahnya guna dimiliki atau dihuni, debitor menggunakan jaminan rumah dan tanah yang dibeli dengan fasilitas kredit dari bank. ${ }^{3}$

Menurut Kartini Muljadi, SKMHT adalah surat kuasa yang benar-benar khusus, hanya terbatas untuk memberikan atau membebankan
Hak Tanggungan semata-mata. ${ }^{4}$ Pembuatan SKMHT bisa ditugaskan kepada PPAT atau notaris yang keberadaannya dalam wilayah kecamatan.

\subsection{Metode Penelitian}

\subsubsection{Jenis Penelitian}

Jenis penelitian yang digunakan adalah penelitian hukum empiris yang berangkat dari kesenjangan antara das solen dan das sein.

\subsubsection{Sifat Penelitian}

Penelitian ini bersifat yuridis-empiris. Penelitian ini sifatnya deskriptif yang artinya menggambarkan sifat-sifat individu, keadaan, gejala atau kelompok tertentu, menentukan penyebaran suatu gejala untuk menentukan adatidaknya hubungan antara satu gejala dengan gejala lainnya dalam masyarakat.

\subsubsection{Data dan Sumber Data}

Dalam penelitian hukum empiris data dapat dibedakan menjadi 2 (dua), yaitu data primer dan data sekunder

\subsubsection{Teknik Pengumpulan Data}

Penelitian ini menggunakan beberapa teknik untuk mengumpulkan data, yaitu Teknik Studi Dokumen dan Teknik Wawancara (interview)

\subsubsection{Teknik Penentuan Sampel Penelitian}

Teknik penentuan sampel yang digunakan dalam penelitian ini adalah teknik non probability sampling.

\subsubsection{Teknik Pengolahan dan Analisis Data}

Data dikumpulkan, diolah dan dianalisa berdasarkan dengan menggunakan teknik pengolahan data secara kualitatif, yaitu memilih data yang kualitasnya dapat memenuhi jawaban dari permasalahan, dan data disusun secara sistematis sehingga memperoleh kesimpulan.
${ }^{3}$ Adrian Sutedi, 2010, Hukum Hak Tanggungan, Sinar Grafika,Jakarta, hal. 196.
${ }^{4}$ Kartini Muljadi dan Gunawan Widjaja, 2005, Hak Tanggungan, Kencana Prenada Group, Jakarta, Hal. 192. 
B AB II

TINJAUAN UMUM TENTANG

KREDIT KEPEMILIKAN RUMAH,

BANK, SURAT KUASA

MEMBEBANKAN HAK

TANGGUNGAN, BANK DAN BUY

BACK GUARANTEE

\subsection{Tinjauan Umum Tentang Kredit}

Kepemilikan Rumah

\subsubsection{Pengertian dan Dasar Hukum Bank dan Kredit}

Menurut ketentuan Pasal 1 angka

2 Undang-Undang No.7 Tahun 1992 yang telah diubah dengan Undangundang No.10 Tahun 1998 Tentang Perbankan (selanjutnya disebut UU Perbankan) "Bank adalah badan usaha yang menghimpun dana dari masyarakat dalam bentuk simpanan dan menyalurkannya kepada masyarakat dalam bentuk kredit dan atau bentuk-bentuk lainnya dalam rangka meningkatkan taraf hidup rakyat banyak".

Menurut ketentuan Pasal 5 ayat (1) UU Perbankan, terdapat dua jenis bank, yaitu Bank umum dan Bank Perkreditan Rakyat (BPR). Definisi kredit secara formal terdapat dalam Pasal 1 angka 11 UU Perbankan yaitu "Penyediaan uang atau tagihan yang dapat dipersamakan dengan itu, berdasarkan persetujuan atau kesepakatan pinjam-meminjam antara Bank dengan pihak lain, yang mewajibkan pihak peminjam, untuk melunasi utangnya setelah jangka waktu tertentu dengan pemberian bunga".
2.1.2 Pengertian dan Dasar Hukum Kredit Pemilikan Rumah

KPR merupakan salah satu jenis kredit usaha kecil (KUK) sebagaimana ditentukan oleh Bank Indonesia. Dalam Surat Keputusan Direksi Bank Indonesia No. 26/24/KEP/DIR tanggal 29 Mei 1993 dalam pasal 2 diatur bahwa salah satu jenis Kredit Usaha Kecil (KUK) adalah kredit pemilikan rumah yang diberikan untuk pengadaan perumahan.

\subsubsection{Asas dan Syarat sahnya Perjanjian} Kredit Kepemilikan Rumah

Sebagaimana telah disebutkan di atas bahwa dari pengertian yang tercantum Pasal 1 ayat (11) UU Perbankan dapat diketahui bahwa kredit merupakan perjanjian meminjam uang antara bank sebagai kreditor dan nasabahnya. Perjanjian berdasarkan Pasal 1313 KUHPerdata perjanjian adalah "Suatu perbuatan dengan mana satu orang atau lebih mengikatkan dirinya terhadap satu orang lain atau lebih." Dari berbagi asas hukum yang terdapat dalam hukum kontrak terdapat empat asas yang dianggap sebagai sakaguru hukum kontrak, yaitu:

1. Asas kebebasan berkontrak

2. Asas konsesualisme

3. Asas pacta sunt servanda

4. Asas itikad baik

\subsubsection{Mekanisme Pemberian Kredit} Kepemilikan Rumah

Mekanisme pemberian kredit merupakan suatu rangkaian kegiatan yang dilakukan oleh bank yang di

5 Agus Yudha Hernoko, 2010, Hukum Perjanjian : Asas Proporsionalitas dalam Kontrak Komersial, Kencana Prenada Media Group, Jakarta, hal. 107 
mulai dari nasabah mengajukan fasilitas kredit sampai dengan kredit tersebut dinyatakan selesai oleh bank.

2.2. Tinjauan Umum Tentang Surat Kuasa Membebankan Hak Tanggungan

2.2.1. Pengertian dan Dasar Hukum Surat Kuasa Memberi Hak Tanggungan

SKMHT adalah surat atau akta yang berisikan pemberian kuasa oleh Pemberi Agunan/Pemilik Tanah (Pemberi Kuasa) kepada Pihak Penerima Kuasa untuk mewakili Pemberi Kuasa guna melakukan pemberian Hak Tanggungan kepada kreditor atas tanah milik Pemberi Kuasa. SKMHT wajib berbentuk akta otentik maka pembuatan SKMHT ditugaskan kepada Notaris dan PPAT selaku pejabat umum yang diberi wewenang untuk membuat akta otentik.

\subsubsection{Pemberian SKMHT dan Hak} Tanggungan Pada Perjanjian KreditKepemilikan Rumah

Dalam KPR debitur memberikan jaminan berupa rumah dan tanah yang dibeli dengan fasilitas kredit dari bank. Bank sebagai pemberi kredit hanya memegang SKMHT, karena hak atas tanah yang dijaminkan dalam perjanjian KPR tersebut belum atas nama pemberi hak tanggungan akibat sertipikat masih merupakan sertipikat induk, belum dipecah secara individual.

2.3 Tinjauan Umum Tentang Perjanjian BuyBack Guarantee

\subsubsection{Pengertian Jenis-jenis Perjanjian dalam KUHPerdata}

KUHPerdata mengenal berbagi jenis perjanjian, salah satunya adalah perjanjian bernama dan tak bernama, yang dapat dilihat dari ketentuan Pasal 1319 KUHPerdata tersebut diatas maka diakui 2 (dua) macam perjanjian dalam Hukum Perjanjian yaitu Perjanjian Nominaat dan Perjanjian Innominaat" 6

\subsubsection{Pengertian dan Dasar Hukum}

\section{Perjanjian Buy Back Guarantee}

Perjanjian buy back guarantee dituangkan dalam bentuk akta Notaris berupa akta buy back guarantee. Akta ini ditandatangani oleh penjamin pada saat perjanjian kredit dan perjanjian pengikatan jaminan dilakukan antara penjamin dengan kreditor, berikut akta-akta accesoir lainnya yang dijumpai dalam perjanjian penjaminan kredit di perbankan. Akta jaminan tersebut dalam hal ini bukan sebagai penjamin utang debitor, tetapi selaku penjamin untuk membeli kembali barang/benda jaminan debitor dalam hal terjadi wanprestasi. Penjamin di sini adalah pihak developer.

2.3.3 Kedudukan Bank dalam Perjanjian Buy Back Guarantee

Menurut Kepala Seksi Kredit Bank BNI Renon, Bapak I.B Rai Adnyana dalam wawancara pada Kamis 10 April 2014 dan KPR Mandiri officer Bank Mandiri Cabang Denpasar, Bapak I Putu Tamiarta dalam wawancara Selasa 8 April 2014, kedudukan bank dalam perjanjian buy back guarantee adalah sebagai penyedia fasilitas KPR yang di Bank BNI disebut sebagai BNI Griya dan di Bank Mandiri disebut KPR Mandiri.

2.3.4 Kedudukan Developer dalam Perjanjian Buy Back Guarantee

Menurut Kepala Seksi Kredit Bank BNI Renon, Bapak I.B Rai

${ }^{6}$ Salim HS., 2005, Perkembangan Hukum Kontrak Innominaat di Indonesia (cet. III), Sinar Grafika, Jakarta, 2005, hal. 6 (selanjutnya disebut Salin H.S II) 
Adnyana dalam kedudukan developer selaku penjamin dalam perjanjian buy back gurantee sangat penting karena jaminan yang diberikan penjamin tersebut merupakan bagian terpenting dari fasilitas KPR Bank BNI yang disebut BNI Griya. Tanpa adanya jaminan tersebut perjanjian fasilitas BNI Griya tidak dibuat dan ditandatangani. (wawancara pada Kamis 10 April 2014)

\section{B AB III}

FAKTOR-FAKTOR YANG MENYEBABKAN DEVELOPER

\section{WANPRESTASI DALAM PENGIKATAN} SKMHT YANG DISERTAI PERJANJIAN BUY BACK GUARANTEE

\subsection{Hubungan Hukum Bank dan Developer dalam Kredit Kepemilikan Rumah}

Menurut KPR Mandiri officer Bank Mandiri Cabang Denpasar, bapak I Putu Tamiarta, hubungan hukum antara bank dan developer dituangkan dalam bentuk perjanjian kerjasama yang dibuat dengan akta tertulis di bawah tangan yang ditandatangani di atas meterai. Isi perjanjian kerjasama disesuaikan dengan keadaan status tanah dan bangunan, kelengkapan dokumen, reputasi developer, dan sebagainya. Jika status jaminan masih dalam bentuk Sertipikat induk maka dalam Perjanjian kerjasama disyaratkan buy back guarantee yang harus dilaksanakan sampai pemecahan sertipikat atas nama debitor, serta AJB dan APHT, ditandatangani oleh debitur.(wawancara pada Kamis 10 April 2014).

Menurut bapak I.B Rai Adnyana, pihak bank setelah bekerjasama dengan developer akan memudahkan dalam penyaluran KPR. Hubungan antara bank dengan developer dituangkan dalam suatu perjanjian kerjasama operasional yang memuat segala hak dan kewajiban para pihak. (wawancara pada Kamis 10 April 2014)

\subsection{Hak dan Kewajiban Bank dan Developer} Dalam Perjanjian Buy Back Guarantee

Dalam perjanjian buy back guarantee kewajiban pihak tidak disebutkan secara jelas. Namun sekalipun demikian kewajiban pihak bank dalam perjanjian tersebut tentu saja adalah menyediakan kredit dalam bentuk dan jumlah yang telah disepakti dalam perjanjian kerjasama yang sebelumnya telah ditandatangani oleh developer dan bank. Sementara itu kewajiban developer selaku penjamin menyangkut beberapa hal; yaitu

1. Menjamin kewajiban debitor kepada bank dengan cara membeli kembali rumah yang telah dibeli debitor kepada penjamin (developer) dengan menggunakan fasilitas KPR dari bank.

2.Penjamin wajib mengikatkan diri untuk menjamin kewajiban debitor pada bank dalam kondisi:

a. Penjamin belum menyelesaikan pembangunan rumah atau

b. Penjamin belum menyerahkan kepada bank dokumen asli, yaitu;

- Sertipikat Hak Atas Tanah yang terdaftar atas nama debitor atau suami/istri atau anak debitor yang merupakan hasil pemecahan atas Sertipikat Induk, IMB atas satuan rumah, Akta jual beli (AJB) dan Akta Pemberian Hak Tanggungan (APHT) dan sertipikat Hak Tanggungan.

3. Pembayaran pembeli rumah oleh penjamin harus berikut bunga tertunggak, denda keterlambatan dan seluruh biaya-biaya yang timbul sehubungan dengan kewajiban angsuran.

4. Penjamin bertanggungjawab sepenuhnya dan bank dibebaskan dari segala akibat yang 
timbul dalam segala hal yang berhubungan dengan debitor dalam kaitannya dengan pembelian kembali rumah yang dibeli debitor.

5. Penjamin dengan ini memberi hak dan wewenang serta kuasa kepada bank untuk setiap saat membebani rekening atas nama penjamin pada bank untuk memenuhi jaminan yang diberikan berdasarkan perjanjian buy back guarantee ini, kuasa mana tidak dapat ditarik kembali dibatalkan atau tidak akan berakhir oleh sebab apapun.

\subsection{Wanprestasi dan Faktor-Fakor Penyebab Developer Wanprestasi Terhadap Perjanjian Buy Back Guarantee}

Mengenai pelaksanaan perjanjian buy back guarantee dalam pemberian fasilitas KPR Mandiri dan BNI Griya, menurut KPR Mandiri officer Bank Mandiri Cabang Denpasar, bapak I Putu Tamiarta dalam wawancara Selasa 8 April 2014 mengaku, Bank Mandiri belum pernah mengalami kondisi wanprestasi oleh developer dalam perjanjian buy back guarantee. Hal senada diungkapkan Kepala Seksi Kredit Bank BNI Renon, I.B Rai Adnyana dalam wawancara pada Kamis 10 April 2014.

Faktor-faktor internal adalah adanya penyalahgunaan fasilitas KPR oleh developer, yaitu karakter developer yang tidak baik, sehingga tidak dapat memenuhi kualitas rumah yang dijanjikan sehingga debitor tidak mau membayar, maka terjadilah keadaan debitor wanprestasi. developer tidak mau membeli kembali rumah yang telah dibeli debitor dengan fasilitas KPR karena jumlah debitor yang menolak membayar atau mengangsur rumah yang dibeli dari developer tersebut sangat banyak.

Sementara itu faktor penyebab eksternal yang membuat developer wanprestasi terhadap perjanjian buy back guarantee adalah kemungkiann terjadinya resesi atau depresi ekonomi sehingga suku bank melonjak drastis seperti kedaan tahun 1998.

\subsection{Akibat Hukum Developer Wanprestasi} Terhadap Perjanjian Buy Back Guarantee

Dalam klausula akta buy back
guarantee yang telah dipaparkan
diatas, diatur bahwa penjaminan
berlaku dalam waktu 7 (tujuh) hari
kerja terhitung sejak peringatan ketiga diberikan kepada debitor oleh kreditor dan debitor tersebut belum melakukan pembayaran maka penjamin harus melaksanakan buy back guarantee. Penjamin tanpa syarat harus membeli kembali tanah dan bangunan yang menjadi agunan debitor. Bilamana dalam waktu yang ditentukan di atas penjamin masih belum membeli kembali tanah dan bangunan berarti penjamin telah wanprestasi dan dalam keadaan demikian penjamin tetap harus melaksanakan buy back guarantee. ${ }^{7}$

\begin{tabular}{|c|c|c|}
\hline Ariadin, & Najamudin, & \\
\hline Gukum & Akta $B l$ & Back \\
\hline $\begin{array}{ll}\text { Guarantee, } & \text { dan } \\
\text { Lembaga } & \text { Per }\end{array}$ & $\begin{array}{l}\text { Implikasinya } \\
\text { bankan”, }\end{array}$ & $\begin{array}{r}\text { Bagi } \\
\text { Jurnal } \\
\end{array}$ \\
\hline Penelitian Hukum & Volume $1 \mathrm{~T}$ & \\
\hline
\end{tabular}
Mei 
BAB IV

UPAYA HUKUM YANG DITEMPUH

BANK DALAM HAL DEVELOPER

WANPRESTASI TERHADAP

PERJANJIAN BUY BACK GUARANTEE

4.1 Upaya Hukum Dalam Hal Developer

Wanprestasi Terhadap Perjanjian Buy

Back Guarantee

$\begin{array}{rrr}\text { Dalam } & \text { perjanjian buy back } \\ \text { guarantee terdapat klausul yang } \\ \text { mengatur masalah penyelesaian }\end{array}$

perselisihan maka para pihak sepakat

menyelesaiakan melalui jalur

musyawarah dan mufakat. Apabila

jalan musyawarah dan mufakat tidak

dapat menyelasiakan perselisihan

maka para pihak sepakat untuk

menyelesaiakan melalui pengadilan.

Langkah yang pertama harus ditempuh pihak bank adalah melakukan musyarwah dan mufakat. Apabila tidak berhasil dapat ditempuh jalur pengadilan, tentu saja prosedur ini akan lebih lama dan panjang karena harus melalui proses gugat menggugat dan dapat melalui beberapa tingkatan peradilan.

\subsection{Penyelesaian Sengketa Antara Bank dan}

Developer Melalui Ligitasi dan Non-

\section{Ligitasi}

Apabila terjadi sengketa antar pihak dalam suatu perjanjian maka dapat ditempuh penyelesaian melalui pengadilan (ligitasi) maupun penyelesaian di luar pengadilan (non litigasi). selain melalui pengadilan (litigasi), penyelesaian sengketa juga dapat diselesaikan di luar pengadilan (non litigasi), yang lazim dinamakan dengan Alternative Dispute Resolution (ADR) atau Alternatif Penyelesaian
Sengketa. ${ }^{8}$ Menurut Pasal 1 angka 10 Undangundang Nomor 30 tahun 1999 tentang Arbritase dan Alternatif Penyelesaian Sengketa (selanjutnya disebut UU Arbitrase dan APS) "Alternatif Penyelesaian Sengketa adalah lembaga penyelesaian sengketa atau beda pendapat melalui prosedur yang disepakati para pihak, penyelesaian di luar pengadilan dengan konsultasi, negosiasi, mediasi, konsiliasi, atau penilaian ahli”.

\subsection{Efektifitas Penyelesaian Sengketa} Melalui Ligitasi dan Non Ligitasi

Menurut Agus Yudha Hernoko penyelesaian sengketa perlu diupayakan penyelesaian yang terbaik dan elegan, penyelesaian cepat, efektif dan efisien. Dalam hal ini penyelesaian terbaik dan ideal adalah adalah pola win-win solution, terutama melalui non litigasi yaitu melalui negosiasi, mediasi, arbritase. $^{9}$

Penyelesaian sengketa melalui pengadilan merupakan penyelesaian sengketa yang paling tua dalam sistem hukum Barat dan bersifat konfrontatif. Penyelesaian sengketa hukum dengan berperkara di muka pengadilan kini mulai dirasakan tidak efektif. Selain membutuhkan waktu cukup lama untuk mendapatkan putusan akhir. Juga menghabiskan dana yang tidak sedikit. Henny Mono mengatakan:

Di kalangan pebisnis penyelesaian sengketa melalui pengsilan dinilai sebagai “jalur primitif" krena terlalu memboroskan waktu. Rentang waktu penyelesaian yang relatif lama, dengan mempertimbangkan laju inflasi, tidak jarang ketika kemenagan sudah dicapai nilai obyek sengketa tidak sebanding dengan keuntungan yang diperoleh. Belum dihitung

${ }^{8}$ Racmadi Usman, 2012, Mediasi di Pengadilan : dalam Teori dan Praktek, Sinar Grafika, Jakarta, hal. 8

${ }^{9}$ Agus Yudha Hernoko, op.cit, hal. 310 
kerugian immaterial para pihak akibat gugat menggugat yang berkepanjangan ${ }^{10}$

\section{BAB V}

\section{PENUTUP}

\subsection{Kesimpulan}

Berdasarkan uraian pada bab-bab sebelumnya dalam tesis ini maka dapat diambil kesimpulan, sebagai berikut:

1. Faktor-faktor yang menyebabkan developer wanprestasi dalam perjanjian SKMHT yang dilengkapi buyback guarantee adalah faktorfaktor internal dan eksternal. Faktor internal adalah adanya penyalahgunaan fasilitas KPR oleh developer sehingga menyebabkan developer tidak dapat memenuhi kualitas rumah yang dijanjikan kepada debitor sehingga debitor tidak mau membayar sehingga terjadilah keadaan debitor wanprestasi.

Faktor penyebab eksternal yang membuat developer wanprestasi terhadap perjanjian buy back guarantee adalah kemungkinan terjadinya resesi atau depresi ekonomi sehingga suku bank melonjak drastis seperti kedaan tahun 1998, akibatnya banyak debitor pembeli rumah tidak memiliki lagi kemampuan mengangsur sehingga mengakibatkan wanprestasi.

2. Upaya yang ditempuh oleh bank apabila developer wanprestasi terhadap perjanjian buy back guarantee dapat berupa upaya di jalur ligitasi dan non ligitasi. Penyelesaian sengketa antara bank dan developer selaku penjamin akibat wanprestasi perjanjian buy back guarantee melalui jalur ligitasi atau dengan berperkara di muka pengadilan tidak efektif karena membutuhkan waktu cukup lama untuk mendapatkan putusan akhir menghabiskan dana tidak sedikit yang terkait dengan lamanya waktu penyelesaian sengketa dan mengalami kerugian immaterial akibat gugat menggugat secara berkepanjangan. Alternatif penyelesaian terbaik bagi kreditor adalah apabila menempuh jalur non ligitasi (di luar pengadilan) atau Alternatif Penyelesaian Sengketa (APS).

\subsection{Saran}

Berdasarkan uraian pada bab-bab sebelumnya dan berdasarkan kesimpulan dari penelitian ini maka dapat disampaikan saransaran sebagai berikut:

\section{Pada Pemerintah}

Pemerintah disarankan menerbitkan undangundang yang khusus mengatur mengenai Perjanjian Buy Back Guarantee sebagai dasar hukum bagi suatu lembaga penjaminan buy buck guarantee yang memiliki kekuatan eksekutorial apabila developer wanprestasi terhadap perjanjian tersebut. Karena belum diatur jelas dalam KUHPerdata.

2. Kepada Bank

a. Harus ada penyempurnaan klausula akta, yaitu mencantumkan klausula buy back guarantee Perjanjian Pengikatan Jual Beli, serta pernyataan tidak keberatan dari debitor, akan menyerahkan secara sukarela, akan menandatangani akte pengalihan untuk dan atas nama developer, apabila debitor wanprestasi, maka debitor menyatakan tidak keberatan jika bank/kreditor akan menjual kembali barang/benda jaminan debitor.

b. Pelaksanaan buy back guarantee oleh developer dilakukan dengan cara mengambil alih utang debitor, membeli kembali barang/benda jaminan dan melunasi utang debitor.

Harus ada dana ditahan bank sebagai jaminan apabila developer wanprestasi

${ }^{10}$ Henny Mono, op.cit, hal. 9 


\section{DAFTAR PUSTAKA}

\section{Buku-Buku}

Adjie, Habib, 2009, Meneropong Khasanah Notaris dan PPAT, Citra Aditya Bakti, Bandung 2011, Hukum Notaris Indonesia : Tafsir Tematik Terhadap UU No. 30 Tahun 2004 tentang Jabatan Notaris, Refika Aditama, Bandung.

Asshiddiqie, Jimly, dan Ali Safaat, 2006, Teori Hans Kelsen Tentang Hukum, Konstitusi Press, Jakarta

Badrulzaman, Mariam Darus, 2001, Kompilasi Hukum Perikatan, Citra Aditya Bakti Jakarta

Hernoko, Agus Yudha, 2010, Hukum Perjanjian : Asas Proporsionalitas dalam Kontrak Komersial, Kencana Prenada Media Group, Jakarta

Muljadi, Kartini dan Gunawan Widjaja, 2005, Hak Tanggungan, Kencana Prenada Group, Jakarta.

Mono, Henny, 2014, Alternatif Penyelesaian Sengketa dan Mediasi, Bayumedia Publishing, Malang

Salim HS, 2005, Perkembangan Hukum Jaminan di Indonesia, Rajagrafindo Persada, Jakarta.

2005, Perkembangan Hukum Kontrak Innominaat di Indonesia (cet. III), Sinar Grafika, Jakarta, 2005

Sutedi, Adrian, 2010, Hukum Hak Tanggungan, Sinar Grafika, Jakarta.

Usman Rachmadi, 2012, Mediasi di Pengadilan : dalam Teori dan Praktek, Sinar Grafika, Jakarta

\section{Majalah/Jurnal}

Eddie Sius Riyadi, 2008, "Landasan Teoritis Bagi Tanggung Jawab Sosial Perusahaan : Dari Pemegang Saham (share holder) ke Pemangku Kepentingan (stake holder), Jurnal Ginitas, Volume V Nomor II

Nadjamudin, Ariadin, 2012, “Aspek Hukum Akta Buy Back Guarantee, dan Implikasinya Bagi Lembaga Perbankan”, Jurnal Penelitian Hukum Volume 1 Tanggal 3 Mei

\section{Tesis}

Gail Henderson, 2009, "The Possible Impact of Enlightened Share Holder Value on Corporation Environmental Performance", A thesis submitted in conformity with the requirements for the degree of Master of Laws Graduate department of the Faculty of Law University of Toronto

\section{Peraturan Perundangan}

Kitab Undang-Undang Hukum Perdata

Undang-Undang No. 4 Tahun 1996 tentang Hak Tanggungan Atas Tanah Beserta Benda-Benda yang Berkaitan Dengan Tanah.

Undang-Undang Nomor 10 Tahun 1998 tentang Perubahan Atas Undang-Undang Nomor 7 Tahun 1992 tentang

Undang-undang Nomor 30 tahun 1999 tentang Arbritase dan Alternatif Penyelesaian Sengketa

Undang-Undang No. 2 Tahun 2014 tentang Jabatan Notaris 
Permendagri Nomor 3 Tahun 1987 tentang Pemberian Hak Atas Tanah Untuk Keperluan Perusahaan Pembangunan Perumahan

Peraturan Menteri Dalam Negeri Nomor 3 Tahun 1987 tentang Penyedian Dan Pemberian Hak Atas Tanah Untuk Keperluan Perusahaan Pembangunan Perumahan

Peraturan Menteri Negara Agraria/Kepala Badan Pertanahan Nasional Nomor 4 Tahun 1996 tanggal 8 Mei 1996 tentang Penetapan Batas Waktu Penggunaan Surat Kuasa Membebankan Hak Tanggungan untuk Menjamin Pelunasan KreditKredit Tertentu.

Peraturan Menteri Agraria /Kepala BPN No. 3/1997

Peraturan Menteri Negara Perumahan Rakyat Nomor 14 Tahun 2010 tentang Pengadaan Perumahan Melalui Kredit/Pembiayaan Pemilikan Rumah Sejahtera Dengan Dukungan Bantuan Fasilitas Likuiditas Pembiayaan Perumahan.

Peraturan Kepala BPN No. 8 Tahun 2012 tentang Perubahan Atas Peraturan Menteri Agraria/Kepala Badan Pertanahan Nasional No. 3 Tahun 1996 tentang Pendaftaran Tanah

$$
* * * * *
$$

